DOI https://doi.org/10.18551/rjoas.2017-12.15

\title{
DETECTION OF STATISTICAL REGULARITIES OF THE RUSSIAN ECONOMY DEVELOPMENT
}

\author{
Ulko S.A., Dmitrenko D.A., students \\ Korneyko O.V.*, Candidate of Economic Sciences \\ Vladivostok State University of Economics and Service, Vladivostok, Russia \\ *E-mail: olga30300@mail.ru
}

\begin{abstract}
Science-based approaches to effective forecasting and planning aimed at minimizing all threats in the socio-economic sphere should be developed in order to increase the contribution to Russia's economic security and the welfare of the country. Studies concerning the meaningful social and economic processes, developing and evolving over time, can help to identify the general patterns of our country's socio-economic development. The purpose of the article is to formulate equations of the analytical dependence of various indicators for forecasting the development of the Russian economy in the future. The methodology used in the study is based on the plotting of chained and basic characteristics of time series, the calculation of mean characteristics of time series, the forecasting of indicators based on chain substitutions, and the trend. The result of the study is the plotting of trend lines for average monthly salaries, per capita cash incomes and inflation rate in the country. On the basis of the results obtained, the main threats to Russia's economic security were identified.
\end{abstract}

\section{KEY WORDS}

Economic security, trend, trend model, threats, development.

"The State Strategy of Economic Security of the Russian Federation» enacted by the Decree of the President of the Russian Federation of May 13, 2017 states: «It is practically impossible to solve any of the tasks facing the country, both domestic and international, without ensuring economic security» [1].

Economic security of the country is the security of economic relations that determine the progressive development of the country's economic potential, improve the well-being of all members in the society and its different social groups, and form the foundations for the nation's defense capabilities.

Effective economic security system is the guarantee of the existence of any country, especially today's Russia, which seeks to take a distinguished position in the world's geopolitical and economic space. The current state of the Russian economy experiencing a second wave of the crisis, which started back in 2008 and has been fueled by the sanctions imposed by Western countries, shows a mix of economic instability signs that indicate problems in the real sector of the economy. The main indicators of instability include a decline in the ruble rate in 2015 by almost a half in comparison with 2014, a decrease in the total consumer demand for many goods and services, and the resulting drop in the living standards of the population, a downturn of small and medium-sized business, and a growing number of bankrupt enterprises [2, 3]. Continuing geopolitical tensions, a possibility of new sanctions, and risks of changes in "rules of the game" by the Russian side are perceived by investors as a major source of additional threats. Foreign and Russian investors' interest in the attractiveness of the Russian economy is rapidly going down.

Solving the task of ensuring security largely depends on the state's purposeful activities to formulate a proper social and economic development strategy. There is, therefore, a pressing need for valuable analytical knowledge, allowing for adequate assessment of the current situation and making an effective decision. 


\section{LITERATURE REVIEW}

Systematic study of academic literature on this issue has revealed a significant number of works of scholars and practitioners. The study of the economic security problem is widely reflected in many scholarly writings of Vorozhbit O., Korneyko O., Burkaltseva D.D., Vorobyov Y., Blazhevich O.G., Frolova E.E., Puhart A.A., and others [4-12]. For example, Senchagov V.K. believes that the main tools for ensuring a secure environment for the development of the Russian economy are "diagnostic assessment and monitoring of the level of threats to the national interests of the country in the field of economics" [13]. Moreover, the major part of further work on the formation of measures aimed at preventing and overcoming such threats is in the monitoring process with which it is possible to identify threats to the security of the Russian economy.

The purpose of the article is to formulate equations of the analytical dependence of various indicators for forecasting the development of the Russian economy in the future. The methodology used in the study is based on the plotting of chained and basic characteristics of time series, the calculation of the mean characteristics of time series, the forecasting of indicators based on chain substitutions, and the trend.

\section{DISCUSSION OF THE RESULTS}

Today's Russia is committed to creating a systematic mechanism for monitoring and assessing the level of threats to the social and economic security of the state. The following parameters are monitored: cash flows of expenses and incomes; changes in the poverty rate; demographic data; indicators of civilian employment and social protection data.

The primary mechanism for integrated monitoring can be considered to be the use of formalized algorithms developed based on mathematical models using the available socioeconomic indicators of relations in said area, instead of traditional intuitive analysis and expert methods [14].

Number of factors that can affect the studied processes regularly increase amid their sufficiently significant differentiation.

The Center for Financial and Banking Studies of Economics Institute used 150 basic indicators for security analysis. The differences of these indicators from other indicators of economic and social activities are that they are able to quantify the economic threats to the state security [13].

Senchagov V.K. suggested using the method of systematizing indicators in the sphere of development of socio-economic systems of the state using the following parameters: sphere of the real economy; demographic indicators; social sphere of the state; external sector of the state; monetary and financial sphere; environmental indicators; area of regional economy; criminal sphere.

The scientist notes that this list of indicators can only be approximate because it should be regularly clarified.

It would also be interesting to focus this study primarily on social and economic indicators of development which include: indicators of dynamic changes in financial incomes of citizens; differentiation of income change indicators in the level of remuneration received; indicators of the ratio of monetary remuneration in calculating the minimum standard of living per capita on average; indicators of wages and the remuneration; indicators of consumption capacity and purchasing power of citizens; indicators of state social assistance for citizens; statistics of growth on the retail market; population employment indicators; data on the provision of citizens with the necessary social services.

The dynamic changes of indicators in the sphere of social and economic development can be clearly demonstrated by plotting trend lines on the graphs which can be shown in the form of the following diagrams (Figures 1-3). The equation of the line, which is a trend model of the required function, will have the form indicated inside each figure. This functional dependence is based on the plotting of chained and basic characteristics of time series, the calculation of the mean characteristics of time series, the forecasting of indicators based on 
chain substitutions, and the trend [6]. Since the graphical representation of the basic data is close to a straight line, the work uses the linear trend equation for analytical smoothing, we used the linear trend equation for analytical smoothing:

$$
\hat{y}_{t}=a+b \cdot t
$$

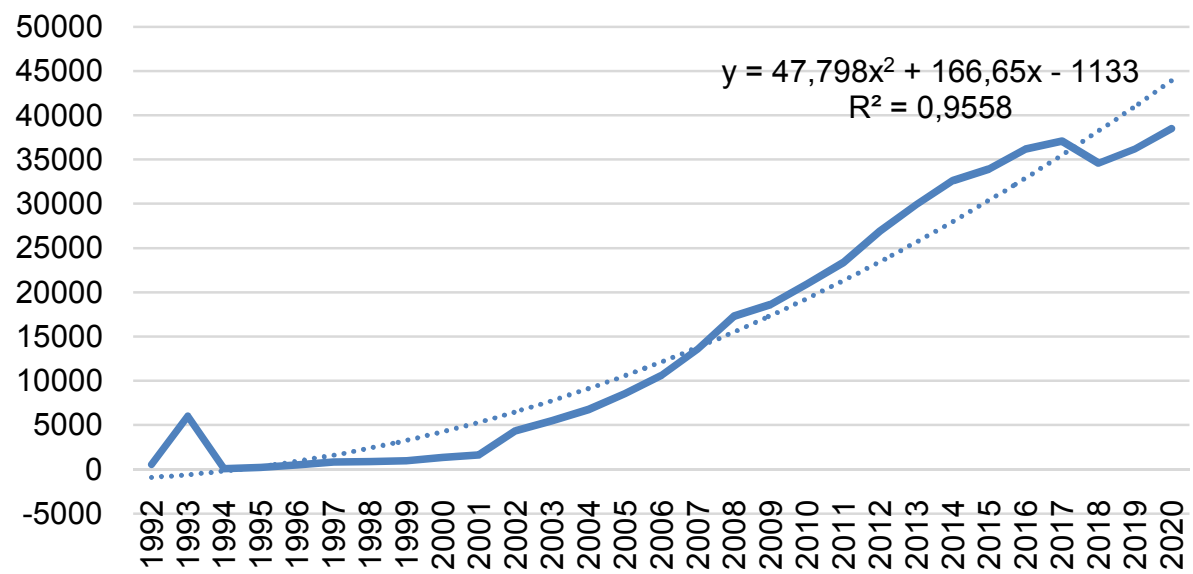

Figure 1 - Dynamics of the average monthly salary in the Russian Federation

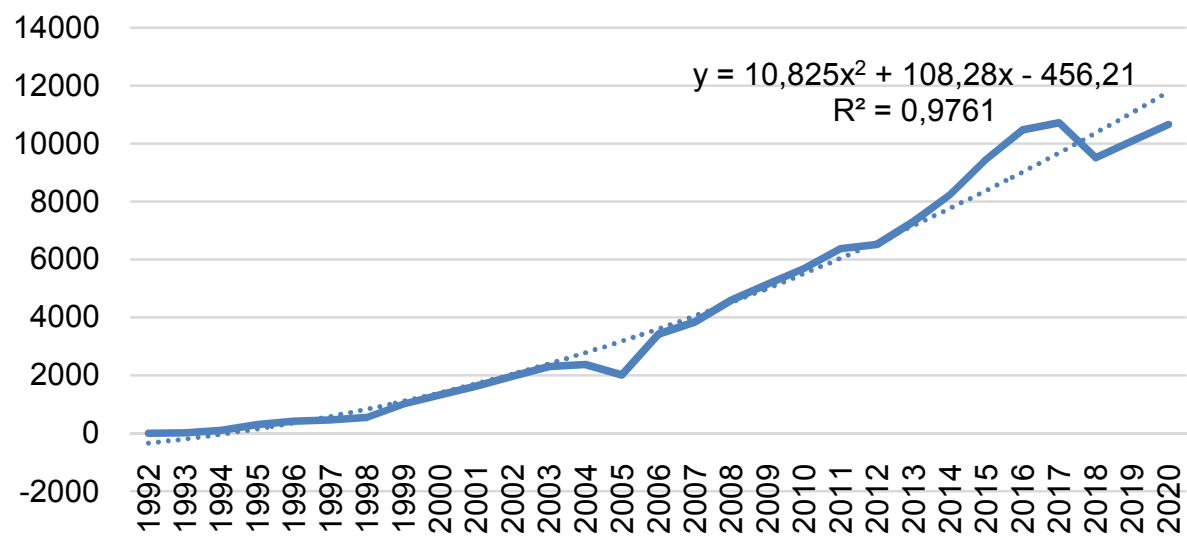

Figure 2 - Dynamics of the minimum subsistence in the Russian Federation

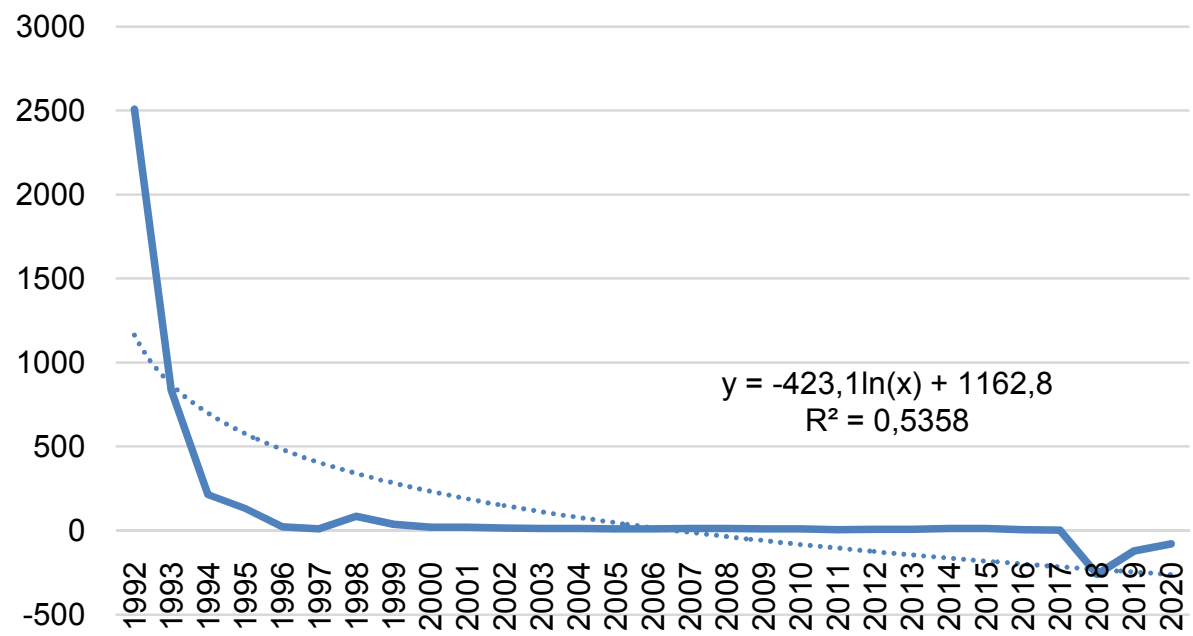

Figure 3 - Dynamics of inflation rates in Russia 
The average error of approximation can change its value to $15 \%$, and this indicates a well-functioning model of the equation. Using these equations, it is possible to obtain the expected values of the indicators with sufficiently high probability.

\section{CONCLUSION}

The presented diagrams demonstrate the dynamic changes in the average monthly payroll and average per capita financial income for the last 15 years. As we can see, it is obvious that the average value of the approximation error does not yield more than $0.5 \%$, which indicates the adequacy of the application of these models and the complete reliability of the obtained indicators during the calculation of the expected budget for the period 20182020. The resulting function increases, and this makes it possible to talk about favorable changes in the parameters of citizens' actual income.

The data on the inflation indices of the Russian Federation for the years 2000 to 2015 show a more sensitive reaction to changes in the socio-economic sector that occur under the influence of some internal and external factors.

At the time of the study of statistical data on inflation indices, the error value of approximation shows $16.6 \%$, and the resulting equation line can only be used with extreme caution to continue the study.

The threats to economic security, in our opinion, can be classified according to their actual impact: the first class of threats has characteristics with a high level of influence and serious economic consequences, for the prevention of which it is necessary to conduct additional comprehensive measures; the second class of threats is characterized by an average level of influence and consequences, for the prevention of which some comprehensive measures are required to be conducted; the third class of threats has a low level of influence and consequences, for the prevention of which preventive measures are sufficient.

It becomes possible to develop effective measures of state policy to address real and perceived threats to economic security by obtaining certain determinants for various security indicators.

\section{REFERENCES}

1. The Presidential Decree of December 31, 2015 No. 683 "On the National Security Strategy of the Russian Federation". Sobranie zakonodatelstva RF [Collection of legislation of the Russian Federation]. 2016. No 1. Article 212. (in Russian).

2. Korneyko O.V, Tsyan L. Otsenka investitsionnoy privlekatelnosti Primorskogo kraya dlya inostrannogo investora [Estimation of the investment attractiveness of Primorsky Krai for a foreign investor]. Vektor nauki Tolyattinskogo gosudarstvennogo universiteta. 2016. №2 (25). pp. 28-35 (in Russian).

3. Markova D.A, Krasova E.V. Razvitie otechestvennogo biznesa

4. $v$ usloviyakh tekuschey makroekonomicheskoy nestabilnosti [The development of domestic business in the current macroeconomic instability]. Vektor nauki Tolyattinskogo gosudarstvennogo universiteta. 2016. №4 (27). pp. 81-87 (in Russian).

5. Korneiko O.V. Value orientations of modern entrepreneurship in Russia. Economic and Social Changes: Facts, Trends, Forecast, 2017, vol. 10, no. 5, pp. 169-183. DOI: 10.15838/esc/2017.5.53.12

6. Vorozhbit O., Korneyko O. Freeport of Vladivostok as the Competitiveness Increase Tool for Russian Fish Export // Social Sciences. 2016. Vol 11. Issue 16. pp. 3962-3968

7. Korneiko O.V. Portovoe hozjajstvo Primorskogo kraja: sostojanie i ocenka ugroz jekonomicheskoj bezopasnosti [Ports of Primorsky region: status and assessment of threats to economic security] // Nacional'naja bezopasnost' / nota bene. - 2017. - №4. pp. 36-49. DOI: 10.7256/2454-0668.2017.4.23170 (in Russian).

8. Ishkinina G. Convergence of the concept «economic security of the state» // The Genesis of Genius. 2015. №2. pp. 45-49. 
9. Burkaltseva D.D. et al. Financial and economic security of business as a primary element in the economic system: calculation of the integrated indicator of economic security // Espacios. 2017. T. 38. №33. pp. 14.

10. Spratlin Ja., Holden K.C. Women and economic security in retirement: implications for social security reform // Journal of Family and Economic Issues. 2000. №1. pp. 37-63.

11. Kaletnik H.M., Pchelianska H.O. Place and role of food security in formation of economic security// Business Inform. 2014. №2. pp. 30-34.

12. Luchyk S.D., Luchyk M.V. Food security assessment as part of the economic security of the country // Problems of economy. 2014. №2. pp. 56-61.

13. Momot T.V. et al. Accounting information security in the system of economic security of enterprise providing // Europaische Fachhochschule. 2014. №10. pp. 123-125.

14. Senchagov V.K. Ekonomicheskaya bezopasnost Rossii [Economic Security of Russia]. Moscow, Laboratoriya znaniy Publ., 2010. 768 p. (in Russian).

15. Denezhkina I.E., Suzdaleva D.A. Sistema pokazateley dlya monitoringa ekonomicheskoy bezopasnosti regiona [System of indicators for monitoring the economic security of the region]. Effektivnoe antikrizisnoe upravlenie. 2011. №3. 97 p. (in Russian).

16. Astafurova I.S. Statistics: Tutorial. Vladivostok, Vladivostok State University of Economics and Service Publ., 2012. 272 p. (in Russian). 